\title{
Preschoolers' Questioning Strategies in Classroom Interactions
}

\author{
Titik Sudartinah ${ }^{凶}$ \\ Ilmu-ilmu Humaniora, Universitas Gadjah Mada \\ Sastra Inggris, Universitas Negeri Yogyakarta \\ DOI: $\underline{10.31004 / o b s e s i . v 5 i 2.785}$
}

\begin{abstract}
Preschoolers often actively participate in conversations by questioning, which come in many forms and serve many functions. This article aims to identify the forms and functions of the questions that preschoolers ask during classroom interactions with their peers and teachers. The research was a qualitative research involving eighteen preschoolers and two teachers. Data were collected by audio-visually recording the questions expressed by the preschoolers during classroom interactions. Their forms and functions were then identified. The findings show that preschoolers mostly use Wh-Questions for both information and non-information seeking, while other forms are mainly for asking for a clarification or confirmation. The employment of these questioning strategies signifies that preschoolers already have the capability of matching the forms of their questions with their functions in order that they can build a complete picture and understanding of the world around them by eliciting, collecting, and synthesizing information from their peers and teachers.
\end{abstract}

Keywords: forms and functions of questions; questioning strategy; preschoolers; classroom interaction.

\begin{abstract}
Abstrak
Anak-anak usia prasekolah seringkali menunjukkan partisipasi aktif dalam percakapan dengan cara bertanya, dengan beragam bentuk dan fungsi. Artikel ini bertujuan untuk mengidentifikasi bentuk dan fungsi pertanyaan yang diajukan oleh anak dalam interaksi di kelas dengan sebaya dan gurunya. Penelitian ini bersifat kualitatif dengan melibatkan 18 anak usia prasekolah dan 2 guru. Data dikumpulkan dengan cara merekam secara audio-visual pertanyaan-pertanyaan yang dituturkan oleh anak-anak tersebut. Bentuk dan fungsi masing-masing pertanyaan kemudian diidentifikasi. Hasilnya menunjukkan bila sebagian besar pertanyaan mewujud dalam bentuk Wh-Questions untuk meminta informasi maupun hal lain yang bukan informasi, sedangkan bentuk-bentuk lainnya terutama dipakai untuk meminta klarifikasi/konfirmasi. Penggunaan berbagai strategi ini menunjukkan bahwa anak usia prasekolah telah memiliki kesadaran untuk memilih jenis pertanyaan tertentu yang sesuai dengan pesan yang ingin mereka sampaikan dalam rangka untuk memaknai dunia sekitar dengan cara meminta, mengumpulkan, dan mensintesakan berbagai informasi yang diperolehnya dari sebaya dan guru.
\end{abstract}

Kata Kunci: bentuk dan fungsi pertanyaan; strategi bertanya; anak usia prasekolah; interaksi di kelas

Copyright (c) 2020 Titik Sudartinah

$\triangle$ Corresponding author:

Email Address : titiksudartinah@uny.ac.id (Yogyakarta, Indonesia)

Received 23 September 2020, Accepted 14 October 2020, Published 18 October 2020 


\section{INTRODUCTION}

Babies naturally learn their first language through interactions with people surrounding them. They start learning the language by imitating the sounds they heard and as they grow older, they become more advanced in recognizing and producing the sounds. Later on, this ability develops to a more sophisticated level, and by preschool age (around 3 to 5 years old), children show the most rapid growth in terms of their language ability (Lust, 2006; Neaum, 2010; Santrock, 2011). Children of this age are able to manage their use of various words, phrases, and sentences in their utterances (Kail, 2011; Oller et al., 2013). As the complexity of the structure of the utterances gradually increases, more messages and information are possible to be expressed through these utterances. In general, this pattern of language development occurs similarly to children regardless of their language and citizenship.

However, there may be differences in terms of the order of the acquisition, since how the children are nurtured need to be taken into account (Clark, 2008; Neaum, 2010; O'Grady, 2005). The environment where the children are nurtured, provides a strong influence toward the development of the children's language. Family is considered by many as the first and most important environment for children (Bryant, 2009; Cowie, 2013; Owens, 2012). It is in the family that children are exposed firstly and mainly to human language. Nevertheless, in the present time, family is not the only environment from which children receive linguistic exposures. More and more children attend schools and spend most of their time there and, therefore, schools become another institution where children learn to build their social and verbal capacity through interactions with their peers and teachers.

This social and verbal capacity is acquired simultaneously in purposeful communications with others. In acquiring this competence, either in the family or at schools, five common strategies are employed by preschool children, i.e. productive strategy, comprehension strategy, functional definition strategy, imitation and repetition strategy, and questioning strategy (Lindfors, 1980; Sidnell, 2010a). As the name suggests, productive strategy is related to the production of a language: children talk a lot and get feedback from their interlocutors. This is quite in contrast to the comprehension strategy, by which children pay more attention to and make some observation on what others are saying. Meanwhile, both the functional definition strategy and imitation and repetition strategy strengthen the idea that language serves mainly a social-affective function for naming objects and expressing thoughts. The last strategy, questioning strategy, is employed when preschoolers want to elicit data from their interlocutors (Sidnell, 2010a).

Some studies were already conducted on these early acquisition strategies. Some are focusing on the productive aspects of language acquisition (Sorsana et al., 2013; Stemberger, 2014; Yang, 2016), comprehension strategy (Mitchell \& Brady, 2013; Rakoczy \& Tomasello, 2009; Wagner et al., 2010), functional definition strategy (Batson-Magnuson, 2017; Fiano, 2014; Negen \& Sarnecka, 2012), imitation and repetition strategy (Oller et al., 2013; Santos et al., 2015; Sidnell, 2010a), and questioning strategy (Bova \& Arcidiacono, 2013; Chouinard, 2007; Rowland, 2007). In the Indonesian context, although there were not many studies on these strategies, there is a study by Solehuddin, Gunawan, \& Kurniawan (2019), revealing that preschool children's productive strategy is marked by the awareness of inflection and derivation in Indonesian morphology.

However, among all other strategies, questioning strategy is less popular. There were not many studies focusing on children's behavior when questioning. One to note was conducted by MacRoy-Higgins \& Kliment (2017) who find out that preschool children often use Wh-Questions to negotiate actions and request information or action. In addition, Valian \& Casey (2003) mention that the use of Wh-Questions is highly dependent on the structure of the input that children receive. Meanwhile, Gauvain, Munroe, \& Beebe (2013) compare how children ask questions in four different non-Western cultures and find that information- 
seeking questions occur relatively similar in any culture but not explanatory questions, which vary across cultures.

The term 'question' is defined by Heritage (2002:1427) as "a form of social action, designed to seek information and accomplished in a turn at talk by means of interrogative syntax". In addition, Ehrlich \& Freed (2010) state that the delivery of questions requires the interlocutors to produce a turn response. By questioning (the act of asking a question), a speaker is initiating a move as it is usually starting an adjacency pair, requiring an answer as its response (Ehrlich \& Freed, 2010; Steensig \& Drew, 2008). This initiation is often marked with a rising intonation at the end of the utterance, showing that the utterance comes in the form of an interrogative. However, there are also utterances that are easily recognized as questions but are expressed formally in constructions other than the interrogatives. This is in line with what Sidnell (2010b:39) states, that "questioning lies at the intersection of form and norm". Certain elements such as interrogative syntax and rising intonation are typical markers of a question, but they can be omitted or replaced once the act of questioning is fulfilled by other elements.

Regarding the various forms that questions may be expressed, Tracy \& Robles (2009) and Sidnell (2010b) suggest that questions can be categorized into Yes-No Interrogatives, YesNo Declaratives, Wh-Questions, Tag Questions, and Alternative Questions. The difference between the use of an interrogative and declarative to question lies in the claim that the speaker makes regarding the answer or response to the question, either he has no knowledge about it or he assumes to know about it (Raymond, 2010; Steensig \& Drew, 2008). Meanwhile, Tag Questions are formed by a combination of assertion and interrogative tag and Alternative Questions are marked by or and the like.

Expressing a question, a speaker is mainly trying to elicit information, particularly in order to build a complete understanding on what is asked. Although the seeking of information about the world is the main function of children's questioning(Chouinard, 2007; Steensig \& Drew, 2008; Tracy \& Robles, 2009), there are some other functions such as to conversationally initiate a move (Steensig \& Drew, 2008), make assertions (Sidnell, 2010b), perform directive acts (Casillas, 2014), show affiliation/disaffiliation (Steensig \& Drew, 2008), ask for a clarification/confirmation (Lindfors, 1999), and exercise control and power (Ehrlich \& Freed, 2010). The successful achievement of these functions is dependent on some factors such as how, to whom, and in what situation the question is delivered.

In the context of preschool classroom interactions, questioning is considered natural in classroom discourse. It forms a mutual interaction between teachers and preschoolers (Carlsen, 1991), showing the creative thought of both in constructing the questions and answering them (Olsson, 2013). Meanwhile, Glaubman, Glaubman, \& Ofir (1997) notice that many questions expressed by preschoolers are purely in search for information mirroring reality. Then, as a consequence, due to increasing age, questioning resembles a social function more and its quantity decreases. This strategy is not only intended for seeking information, but also intended for achieving some other goals, such as requesting in a polite manner and asking for attention.

The ability to question and how certain strategies are employed when questioning, thus, is an important aspect of preschoolers' language development and it deserves more attention. Studies on these will of course provide some contribution to build a comprehensive picture of preschoolers' language development. However, the topic of children's questions is not explored yet in Indonesian context. Previous studies conducted on questioning strategy were mainly researching teachers' questioning in the classroom (Amalia \& Devanti, 2016; Sunggingwati \& Nguyen, 2013), young adult students' use of questions (Zaim, 1998), and the acquisition of interrogatives (Rohmah et al., 2019). None has been conducted on how younger children employ questioning strategies when they are involved in conversations, either with their peers or adults. 
Therefore, in order to fill the gap, this article focuses on preschoolers' questioning strategies in classroom interactions with teachers and peers, especially on the forms and functions of the questions. Educators, parents, and readers in general can benefit from reading this article. Theoretically they can get some new insights regarding the use of questions by preschoolers during classroom interactions and practically can use this as an example of further research on preschoolers' language development.

\section{METHODS}

The research was a qualitative study conducted at Madukismo Playgroup, which is located in Bantul Regency, Yogyakarta. Madukismo Playgroup is one of leading playgroups in Bantul Regency. It was established in 1960 and is nationally accredited with an excellent grade. Initially serving children of the employees of Madukismo Sugar Factory, the playgroup now provides services for outsiders as well. In the academic year 2018/2019, there were 18 children joining the playgroup, consisting of 9 boys and 9 girls, whose age range from 3 to 4.9 years old.

The participants of this research were all these 18 preschoolers with their 2 teachers. Before the data collection began, a consent form was sent to parents to seek their permission for these preschoolers to participate in the research. The data were collected during classroom interactions in a one-week period at the end of the academic year 2018/2019. The classroom interactions between the preschoolers and their peers as well as their teachers were audiovisually recorded for one hour each day and then transcribed orthographically using ELAN 5.5 software.

Although the study employed a qualitative design, both qualitative and quantitative data were used. The qualitative data were the questions expressed by the preschoolers during classroom interactions. They were identified, coded, and classified based on their forms and functions. Meanwhile, the quantitative data include the frequency and percentage of the questions, which is important to support the description of the qualitative data.

The collection of data was done naturally through observations during classroom interactions, without any intervention from the researcher. The researcher recorded the classroom interactions between preschoolers and their peers and teachers using several smartphones. The smartphones were hidden somewhere in the classroom, at places where preschoolers' moves can be captured clearly, so that the preschoolers are unaware of the presence of such devices, yet their activities are well-documented. Meanwhile, the data analysis was conducted using the theories of questioning strategy by Chouinard (2007), Steensig \& Drew (2008), and Tracy \& Robles (2009). A narrative form of description was chosen to present the results of the analysis of qualitative data and a table indicating the frequency and percentage of the occurrence of questions was the means of presenting the quantitative data to support the narrative description.

\section{RESULTS AND DISCUSSION}

The findings of the research show that there are 132 questions expressed by the preschoolers in Madukismo Playgroup during classroom interactions with peers and teachers. These questions come in 4 forms and serve 2 main functions, which then can be detailed into 5 functions. These are presented in Table 1, showing the frequency and percentage of the questions found in preschoolers' utterances.

Table 1 shows that there are four types of questions expressed by the preschoolers. Most of the questions come in the form of Wh-Questions (65.1\%). Other forms also exist, but more limited in terms of the occurrence. They are Yes-No Declaratives (20.5\%), Yes-No Interrogatives (12.1\%), and Tag Questions (2.3\%). The form of Alternative Questions, usually marked by the use of or and the like, does not appear in the data as in all cases where questions occur, the preschoolers are not in the situation where they have the options to choose anything. 
All conversations are about objects and play activities with a lot of information sharing and inquiries.

Table 1. The Forms and Functions of Preschoolers' Questions in Classroom Interactions

\begin{tabular}{|c|c|c|c|c|c|c|c|}
\hline \multirow[t]{2}{*}{ No } & \multirow[t]{2}{*}{ Functions } & \multicolumn{4}{|c|}{ Forms } & \multirow[t]{2}{*}{ Frequency } & \multirow[t]{2}{*}{$\%$} \\
\hline & & $\begin{array}{c}\text { Wh- } \\
\text { Questions }\end{array}$ & $\begin{array}{c}\text { Yes-No } \\
\text { Declaratives }\end{array}$ & $\begin{array}{c}\text { Yes-No } \\
\text { Interrogatives }\end{array}$ & $\begin{array}{c}\text { Tag } \\
\text { Questions }\end{array}$ & & \\
\hline \multirow[t]{3}{*}{1} & Information-seeking & & & & & & \\
\hline & $\begin{array}{l}\text { a. } \\
\text { infoeking } \\
\text { about facts }\end{array}$ & 50 & 5 & 2 & 0 & 57 & 43.2 \\
\hline & $\begin{array}{ll}\text { b. } & \text { Seeking } \\
\text { explanation }\end{array}$ & 15 & 1 & 3 & 0 & 19 & 14.4 \\
\hline \multirow[t]{7}{*}{2} & Non-information se & king & & & & & \\
\hline & $\begin{array}{l}\text { a. Asking for } \\
\text { clarification/ } \\
\text { confirmation }\end{array}$ & 9 & 14 & 6 & 3 & 32 & 24.3 \\
\hline & $\begin{array}{l}\text { b. Asking for } \\
\text { attention }\end{array}$ & 11 & 0 & 0 & 0 & 11 & 8.3 \\
\hline & $\begin{array}{l}\text { c. Asking for } \\
\text { permission }\end{array}$ & 0 & 4 & 5 & 0 & 9 & 6.8 \\
\hline & $\begin{array}{l}\text { d. Requesting an } \\
\text { action }\end{array}$ & 1 & 3 & 0 & 0 & 4 & 3 \\
\hline & Frequency & 86 & 27 & 16 & 3 & 132 & \\
\hline & $\%$ & 65.1 & 20.5 & 12.1 & 2.3 & & 100 \\
\hline
\end{tabular}

Meanwhile, the questions serve two main purposes: information seeking and noninformation seeking. The information seeking questions are seeking information about fact $(43.2 \%)$ and seeking explanation (14.4\%). On the other hand, non-information seeking questions include questions used for asking for clarification $(24.3 \%)$, attention $(8.3 \%)$, and permission $(6.8 \%)$, and requesting an action (3\%). In terms of the interrelation between the forms and functions of preschoolers' questioning strategy, it is seen that Wh-Questions are used either for seeking information or for something other than information. Other forms, YesNo Declaratives, Yes-No Interrogatives, and Tag Questions, are mainly used for asking for a clarification or confirmation.

\section{Strategy 1: The Use of Wh-Questions}

Tracy \& Robles (2009) supported by Sidnell (2010b) mention that questions can be classified into 5 types, i.e. Yes-No Questions, Wh-Questions, Declarative Questions, Tag Questions, and Alternative Questions. Among these types, only 4 occur in the data: WhQuestions, Yes-No Declaratives, Yes-No Interrogatives, and Tag Questions. Wh-Questions begin with question words like who, what, where, when, why, and how. The Indonesian terms for these question words are siapa, apa, di mana, kapan, mengapa, and bagaimana. When informally used, mengapa (why) is sometimes replaced with kenapa and bagaimana (how) with gimana.

Among these question words, when is the only question word that does not appear in the data. When is used when a speaker wants to ask about time. Meanwhile, all of the conversations involving preschoolers in Madukismo Playgroup set in the present time, without any context of past or future time. In consequence, there are no changes in terms of the temporal aspects of these conversations. This clearly marks one of the characteristics of children language regarding the concept of here-and-now, which believes that children in most of their time talk about something that is present near them at the present time (Ehrlich \& Freed, 2010; Kail, 2011). 
Meanwhile, all other question words occur in the data. Preschoolers use them as their strategy to question about the detailed description of a person, an object, or an activity. Table 2 presents the functions of preschoolers' strategy of using question words when interacting with their peers and teachers in Madukismo Playgroup.

Table 2. The Use of Question Words in Preschoolers' Questions

\begin{tabular}{|c|c|c|c|c|}
\hline No & $\begin{array}{l}\text { Question } \\
\text { word }\end{array}$ & Frequency & Information seeking & $\begin{array}{c}\text { Non-information } \\
\text { seeking }\end{array}$ \\
\hline 1. & what & 37 & $\begin{array}{l}\text { a. Asking for information about the } \\
\text { details of an object (name, } \\
\text { appearance, and description) } \\
\text { e.g. } \\
\text { (1) Bu, itu apa? (Miss, what is that?) } \\
\text { (2) Kamu bawa apa itu? (What do you } \\
\text { bring?) } \\
\text { (3) Bu, ikan paus maemnya apa? (Miss, } \\
\text { what does a whale eat?) } \\
\text { b. Asking for information regarding a } \\
\text { concept or definition } \\
\text { e.g. } \\
\text { (4) Satu itu apa? (What is 'one'?) } \\
\text { c. Asking for information about } \\
\text { activities } \\
\text { e.g. } \\
\text { (5) Itu dia mau ngapain? (What does she } \\
\text { intend to do?) }\end{array}$ & $\begin{array}{l}\text { Asking interlocutor to } \\
\text { clarify/repeat his } \\
\text { statement } \\
\text { e.g. } \\
\text { (6) Apa? (What?) }\end{array}$ \\
\hline 2. & where & 20 & $\begin{array}{l}\text { Asking for information about location } \\
\text { of an object (toy, stationery) or person } \\
\text { e.g. } \\
\text { (7) Bu Guru, lemnya di mana? (Miss, } \\
\text { where is the glue?) } \\
\text { (8) Bu Guru, di mana Bu Guru? (Where is } \\
\text { the teacher?) } \\
\text { (9) Kamu mau ke mana? (Where do you } \\
\text { want to go?) }\end{array}$ & $\begin{array}{l}\text { Asking for an attention } \\
\text { from the interlocutor } \\
\text { e.g. } \\
\text { (10) Itu petiknya dari } \\
\text { mana? (Where do } \\
\text { you get it?) }\end{array}$ \\
\hline 3. & who & 15 & $\begin{array}{l}\text { a. Asking for information about the } \\
\text { doer of an action } \\
\text { e.g. } \\
\text { (11) Siapa yang sedang perosotan? (Who is } \\
\text { sliding at the playground?) } \\
\text { b. Asking for information about the } \\
\text { owner of an object (toy or } \\
\text { stationery) } \\
\text { e.g. } \\
\text { (12) Bu Guru, ini pensilnya punyanya } \\
\text { siapa? (Miss, whose pencil is this?) }\end{array}$ & $\begin{array}{l}\text { Asking for an attention } \\
\text { from the interlocutor (in } \\
\text { the context of pretend } \\
\text { play) } \\
\text { e.g. } \\
\text { (13) Anak-anak, siapa yang } \\
\text { mau bermain perahu? } \\
\text { (Kids, who want to } \\
\text { go boating?) }\end{array}$ \\
\hline 4. & why & 10 & $\begin{array}{l}\text { Asking for some explanation } \\
\text { e.g. } \\
\text { (14) Kok ini nyala? (Why is it on?) } \\
\text { (15) Kenapa ditaruh sini? (Why do you } \\
\text { put it here?) }\end{array}$ & \\
\hline 5. & how & 4 & $\begin{array}{l}\text { Asking for some information about } \\
\text { how something is done } \\
\text { e.g. } \\
\text { (16) Tapi caranya gimana? (But how does } \\
\text { it work?) }\end{array}$ & $\begin{array}{l}\text { Requesting an action } \\
\text { e.g. } \\
\text { (17) Bagaimana kalau kita } \\
\text { bikin itu? (How } \\
\text { about making it?) }\end{array}$ \\
\hline
\end{tabular}


As presented in Table 2, five question words (what, where, who, why, and how) are used in the questions addressed by preschoolers in Madukismo Playgroup to their peers and teachers. What is the most dominant one as these children often inquire about the details of an object or person, especially asking for its name, physical appearance, and description. The objects that are mostly talked about in the conversations are toys, stationery, and profession, as they belong to the immediate context where the preschoolers are present, i.e. the learning process in the classroom and all associated with media and plaything available in the classroom. Meanwhile, the persons that become the topic of the conversations are the preschoolers themselves, their teachers, families, and main characters in movies. Question (1) and (2) in Table 2 are examples of preschoolers' questions that ask some information regarding an object's name and how the object look like, while example (3) Bu, ikan paus maemnya apa? (Miss, what does a whale eat?) is implicitly inquiring the description of what a whale eats.

In addition, what is also used for questioning about a concept or definition. Curiosity becomes the main reason for the preschoolers to ask questions to seek information regarding this, either from their peers or teachers. Whenever they hear anything unfamiliar or something familiar but without any knowledge regarding its definition, they will immediately ask questions, such as presented in example (4) Satu itu apa? (What is 'one'?). Although the word satu (one) is frequently heard and used by preschoolers, it is not easy for them to understand what the word really means. Therefore, asking such a question, the preschooler wants to know the definition of the abstract concept used for counting 'one'. Another use of what by preschoolers is to seek information regarding an activity, such as in example (5) Itu dia mau ngapain? (What is she doing?). The question occurs when two preschoolers in a conversation are talking about one of their friends who is running outside the classroom. They feel curious about what their friend will do outside. The speaker is aware that by asking such a question he will probably get an answer as what he expects.

Seeking information is not the only goal of preschoolers' strategy of using what in their questions. They are also able to seek for something other than information, such as to ask their interlocutor to clarify or repeat his statement as presented in example (6) Apa? (What?). Appearing alone, the question word what here signals the speaker's lack of understanding regarding the utterance of his interlocutor and he wants his interlocutor to provide some clarification or to repeat the statement in order to increase his level of understanding.

The second question word found in preschoolers' strategy of using Wh-Questions is where, which is typically used for seeking information regarding a place or location. Examples (7), (8), and (9) well represent this function. All these three questions are expressed to ask about where the glue is placed (7), where the teacher is (8), and the place to which a preschooler is going (9). Although where is literally used for asking about a location, it is interesting to note that when it is used in a certain context, the utterance might not be really asking for a location only, such as in example (10) Itu petiknya dari mana? (Where do you get it?). Without any knowledge regarding the context of the question, anyone can simply understand that the question literally asks about a location. However, in this context, it is a repeated question. Repeating this question, the speaker wants to gain attention from his interlocutor, showing the importance of the required information by placing an emphasis on the information he asks for.

The next question word used in the Wh-Questions expressed by preschoolers in Madukismo Playgroup is who, which is specifically used for asking about the doer of an action, such as in example (11), and the owner of an object, such as in example (12). In addition, besides seeking information, the question word who is also for asking for attention from the preschoolers' interlocutors. This occurs in the context of pretend play among the preschoolers, which is clearly presented in example (13) Anak-anak, siapa yang mau bermain perahu? (Kids, who want to go boating?). The speaker of this utterance is one of the preschoolers in Madukismo Playgroup who pretends to be a tour leader. The utterance functions to attract his peers to listen to him as they are running to and fro in the room. 
Meanwhile, the question word why is only used by the preschoolers to ask for some explanation from their interlocutors. The explanation that is sought is usually related to their current activities and things associated with these activities. For instance, through utterance (14) Kok ini nyala? (Why is it on?), the speaker inquires some explanation from her teacher regarding the classroom lamp. It is on although the class is well-sunlit. A similar inquiry of explanation occurs in utterance (15) Kenapa ditaruh sini? (Why do you put it here?). The utterance occurs during a painting activity. A preschooler is approaching the speaker with a handful of toys and put them next to her. Feeling annoyed, the speaker is questioning her peer's reason for doing that.

The last question word found in the data is how, which is used when a preschooler wants to know how something is done, such as in example (16) Tapi caranya gimana? (But how does it work?). The speaker of utterance (16) expresses her intention of knowing how to make a cotton cloud on a paper. She asks the teacher for some explanation about this. The question word how is also used when preschoolers want to invite their peers to join an activity. An example representing this is example (17) Bagaimana kalau kita bikin itu? (How about making it?). In the toy corner, the speaker of this utterance invites his peers for a joint activity of making something using building blocks.

\section{Strategy 2: The Use of Yes-No Declaratives}

Using Yes-No Declaratives is the second strategy of questioning done by preschoolers in Madukismo Playgroup. A Yes-No Declarative is quite similar to Yes-No Interrogative in terms of function, but it is a bit different in terms of its form. It is formally a declarative sentence in terms of form but has the function of a question, while a Yes-No Interrogative is clearly a question both in terms of form and in terms of function. Therefore, a Yes-No Declarative is often categorized as a part of Yes-No Interrogative that has no associated syntactic marker due to its omission by the speaker (Weber, 1993). One way to interpret whether a declarative utterance is a question is by observing its terminal intonation. A rising terminal intonation unambiguously signals a question. In addition, using a Yes-No Declarative, a speaker is assumed to have some prior knowledge regarding the answer to the question and wants to ask for some clarification or confirmation (Raymond, 2010). This occurs as well in children language, bringing this as the main function of the use of a Yes-No Declarative.

This is a similarly occurring phenomenon in Madukismo Playgroup. Out of 27 data of Yes-No Declaratives, 14 of them are intended for asking for a clarification/confirmation. YesNo Declaratives become the main questioning strategy chosen by the preschoolers in Madukismo Playgroup if they are inquiring a clarification/confirmation from their interlocutors. Both rising terminal intonation and omission of question word are employed, making their Yes-No Declaratives easy to spot.

An example of Yes-No Declaratives in the questions expressed by the preschoolers in Madukismo Playgroup is in utterance (18) Kamu jadi kakaknya ya? (You are the brother, right?). The utterance takes place in a pretend play among preschoolers in Madukismo Playgroup. They are acting as a family, consisting of a father, mother, sons and daughters. One of the preschoolers, who become a son is asking another preschooler whether he is her brother. What she did is actually asking for a confirmation from her peer as she already knows his role in the play. The word ya (right) at the end of the utterance clearly marks the confirmation-seeking of this Yes-No Declarative.

Another example of the function of asking for clarification/confirmation in Yes-No Declaratives is presented in utterance (19) Kamu beli? (You buy this?). Although there is no associated lexical marker of a question in the utterance, the rising intonation at the end of the utterance can be used as the basis for determining this as a question. The conversation is between two preschoolers who are discussing the snacks brought to school by one of them. 
Here, the speaker of utterance (19) already knows that his peer bought the food somewhere, yet he wants to make sure that his claim is right by seeking confirmation from his peer.

Besides functioning as a request for clarification/confirmation, Yes-No Declaratives are also used by the preschoolers in Madukismo Playgroup to ask for some information about fact, such as shown in utterance (20) Meteor itu bintang? (A meteor is a star?). The utterance is addressed to the teacher and it takes place during a class discussion on solar system. Bintang (star) is a common and familiar word for preschoolers, but not meteor. Therefore, in order to have some information on what a meteor is, the preschooler associates it with the word bintang (star) that he already knows and is also mentioned in the discussion. He chooses a Yes-No Declarative strategy to obtain this information to show his understanding of the association between a meteor and a star.

The next function represented through the use of Yes-No Declarative strategy is the function of seeking explanation. Unlike Wh-Questions strategy that uses why to literally ask for some explanation from the interlocutor, Yes-No Declarative has no words marking this function. To interpret a Yes-No Declarative to bring this function, one must examine the context of the question as well as the suprasegmental elements, such as its intonation. An instance of the use of Yes-No Declarative to represent this function is utterance (21) Gambarnya dicoret? (The drawing damaged?). This utterance is expressed by a preschooler who found out that his drawing has just been scratched by one of his peers. He is so disappointed and asks the teacher for help. Although the question word why is not used in the utterance, it is clearly seen that the speaker is questioning the reason for such action to happen. Besides, he implicitly asks for some help from the teacher, so similar actions will not repeatedly occur.

There are two more functions brought by Yes-No Declaratives in the utterances produced by preschoolers in Madukismo Playgroup, i.e. requesting an action and asking for permission. For instance, utterances (22) Jangan dirusakin ya? (Don't break it, okay?) and (23) Mainan sama aku? (Play with me?) are both requesting an action. The action requested by the speaker through utterance (22) is the action of being careful in using toys during play activities. Through utterance (23), the speaker invites her interlocutor to play with her. Both utterances are indirect directive speech acts, by which an action is requested without being formally expressed in an imperative mood. Meanwhile, the other function of the use of Yes-No Declaratives is for asking for permission, such as in (24) Aku ini? (I take these?), that occurs during a class drawing activity. Addressing this utterance to his teacher, the preschooler wants to ask for his teacher's permission for taking and using the color pencils on the teacher's desk.

\section{Strategy 3: The Use of Yes-No Interrogatives}

Compared to a Yes-No Declarative, a Yes-No Interrogative is easier to identify as it is interrogatively formatted. In English, its typical form is Auxiliary Verb + Subject + Main Verb. Meanwhile, in Indonesian, this type of question is usually marked with the use of particle kah (Alwi et al., 2010; Pandean, 2018; Setyadi, 2018). Unlike a Yes-No Declarative, using a YesNo Interrogative, the speaker has no prior claim regarding the possible answer to the question. Therefore, the use of this question type is for gathering relevant information as what is inquired (Raymond, 2010).

Some examples of the use of Yes-No Interrogative in the utterances produced by the preschoolers in Madukismo Playgroup are utterance (25) Bolehkah kupinjam mas? (Can I borrow it, Bro?) and (26) Cuci tangan nggak? (Shan't we wash our hands?). In utterance (25), the interrogative form is marked with the particle -kah that is attached to the word boleh (can). In other cases, probably this particle is attached to different slots in an interrogative sentence since one of its characteristics is its ability of free distribution. Utterance (25) takes place during a play activity. A preschooler is asking one of his peers for permission to borrow his toys. Using this type of question, the preschooler has no idea whether or not his request for permission will be granted. Besides $-k a h$, negation can also be used to mark a Yes-No Interrogative, such as in (26) Cuci tangan nggak? (Shan't we wash our hands?). This utterance 
is expressed by a preschooler after break before going back into the classroom. He seek information from his interlocutor about the necessity of washing hands before the next activity begins.

The third function of the use of Yes-No Interrogatives by preschoolers in Madukismo Playgroup is asking for clarification/confirmation, such as in utterance (27) Itu permen lipstik ya? (Is it a lipstick candy?). Here, the speaker asks for the interlocutor's clarification/confirmation about the candy, which is signaled by the particle ya at the end of the utterance. Other particles signaling the need of clarification/confirmation from the interlocutor are apa and kan (Pandean, 2018). However, they do not occur in the construction of Yes-No Interrogatives by the preschoolers in Madukismo Playgroup, but in Tag Questions.

\section{Strategy 4: The Use of Tag Questions}

There are three instances of Tag Questions spoken by the preschoolers in Madukismo Playgroup. All of them are employed to ask for clarification/confirmation from the interlocutors. A Tag Question is typical in form, i.e. a declarative or imperative sentence plus an interrogative fragment in a contrasting mood.

The first example is utterance (28) Basah, kamu nggak basah kan? (You are wet, aren't you?). In the first part of the utterance, the speaker states that his interlocutor is wet, then it is followed by its negation and the particle kan. The occurrence of both positive and negative mood in this utterance makes it belong to a tag question, requesting a yes/no answer for confirming the proposition. In addition, as a particle marking a confirmation question, the particle kan at the end of this utterance strengthens the speaker's inquiry regarding his interlocutor's condition, whether he is wet or not.

Another example is utterance (29) Ini namanya pemakaman, ya bukan? (This is a cemetery, isn't it?). This utterance takes place in a pretend play in which several preschoolers in Madukismo Playgroup participate. They pretend to be in a cemetery, discussing their fear of ghosts and the like. The speaker of utterance (29) asks his peer to provide a clarification/confirmation about the name of the place. The form of a Tag Question is observable through the use of particle $y a$ and the negation bukan (not).

To sum up, it is highly noticeable that preschoolers already develop an awareness regarding how they express questions during classroom interactions with their teachers and peers. They mainly use Wh-Questions as the main strategy since it offers them the flexibility of asking a wide range of information, from facts to explanation, as well as to simply ask for some clarification/confirmation or call for an attention from their interlocutors. In addition, since preschool age is ty pically marked with a high level of curiosity (Gauvain et al., 2013), the questions are mainly expressed to collect various information to develop preschoolers' comprehensive understanding about the world.

\section{CONCLUSION}

When questioning, either to their peers or teachers, preschoolers carefully manage which form that fits a function to improve their understanding of the world. They mostly use Wh-Questions in which all question words but kapan (when) are used. It is not used since the time frame of the conversations among preschoolers is always at present. This evidently shows a typical characteristic of children language - the here-and-now principle. This strategy is employed when the preschoolers want to seek information about facts and explanation and to ask for something other than information. Meanwhile, other strategies are mostly for asking for some clarification/confirmation from the preschoolers' interlocutors. The particles -kah, $a p a, y a$, and kan are used as markers signaling this function in the preschoolers' utterances.

\section{ACKNOWLEDGMENTS}

I would like to thank all the preschoolers, parents, and teachers in Madukismo Playgroup for their participation in the research. As this is a part of my dissertation project, I 
DOI: 10.31004/obsesi.v5i2.785

would also like to express my sincere gratitude to my supervisors, Prof. Dr. I Dewa Putu Wijana, S.U., M.A. and Dr. Aris Munandar, M.Hum. for their guidance and support during my study.

\section{REFERENCES}

Alwi, H., Dardjowidjojo, S., Moeliono, A. M., \& Lapoliwa, H. (2010). Tata Bahasa Baku Bahasa Indonesia (3rd ed.). Pusat Bahasa dan Balai Pustaka.

Amalia, A. R., \& Devanti, Y. M. (2016). The use of questioning strategy to improve students' reading comprehension. Journal of English Language, Literature, and Teaching, 01(2), 8188 .

Batson-Magnuson, L. (2017). An analysis of the relationship between phonological and nonphonological language and early reading development. Communication Disorders Quarterly, 38(2), 78-88. https:/ / doi.org/10.1177/1525740116644891

Bova, A., \& Arcidiacono, F. (2013). Investigating children's Why-questions: A study comparing argumentative and explanatory function. Discourse Studies, 15(6), 713-734. https:/ / doi.org/10.1177/1461445613490013

Bryant, J. B. (2009). Pragmatic development. In E. L. Bavin (Ed.), The Cambridge Handbook of Child Language. Cambridge University Press.

Carlsen, W. S. (1991). Questioning in Classrooms: A Sociolinguistic Perspective. Review of Educational Research, 61(2), 157-178. https://doi.org/10.3102/00346543061002157

Casillas, M. (2014). Turn-taking. In D. Matthews (Ed.), Pragmatic Development in First Language Acquisition (pp. 53-70). John Benjamins Publishing Company. https://doi.org/10.1075/tilar.10.04cas

Chouinard, M. M. (2007). Children's questions: A mechanism for cognitive development. In Monographs of the Society for Research in Child Development (Vol. 72, Issue 1, pp. 1-121). https://doi.org/10.1111/j.1540-5834.2007.00413.x

Clark, E. V. (2008). Pragmatics and Language Acquisition. In L. R. Horn \& G. Ward (Eds.), The Handbook of Pragmatics (pp. 562-577). Blackwell Publishing Ltd. https://doi.org/10.1002/9780470756959.ch25

Cowie, H. (2013). From Birth to Sixteen. In From Birth to Sixteen. Routledge. https://doi.org/10.4324/9780203126356

Ehrlich, S., \& Freed, A. F. (2010). The Function of Questions in Institutional Discourse. In A. F. Freed \& S. Ehrlich (Eds.), Why Do You Ask?: The Function of Questions in Institutional Discourse (pp. 1-24). Oxford University Press. https://doi.org/10.1093/acprof:oso/9780195306897.003.0001

Fiano, D. A. (2014). Primary discourse and expressive oral language in a kindergarten student. Reading Research Quarterly, 49(1), 61-84. https:// doi.org/10.1002/rrq.64

Gauvain, M., Munroe, R. L., \& Beebe, H. (2013). Children's questions in cross-cultural perspective: A four-culture study. Journal of Cross-Cultural Psychology, 44(7), 1148-1165. https://doi.org/10.1177/0022022113485430

Glaubman, R., Glaubman, H., \& Ofir, L. (1997). Effects of self-directed learning, story comprehension, and self-questioning in kindergarten. The Journal of Educational Research, 90(6), 361-374.

Heritage, J. (2002). The limits of questioning: negative interrogatives and hostile question content. Journal of Pragmatics, 34, 1427-1446.

Kail, R. V. (2011). Children and their development (6th Edition). In Children and their Development (6th ed.). Pearson Education, Inc.

Lindfors, J. W. (1980). Children's Language and Learning. Prentice-Hall.

Lindfors, J. W. (1999). Children's Inquiry: Using Language to Make Sense of the World. Teachers College Press.

Lust, B. C. (2006). Child language: Acquisition and growth. In Child Language: Acquisition and Growth. Cambridge University Press. https://doi.org/10.1017/CBO9780511803413 
MacRoy-Higgins, M., \& Kliment, S. (2017). Pragmatic functions in late talkers: A 1-year followup study. Communication Disorders Quarterly, 38(2), 107-111. https:// doi.org/10.1177/1525740115627344

Mitchell, A. M., \& Brady, S. A. (2013). The effect of vocabulary knowledge on novel word identification. Annals of Dyslexia, 63(3), 201-216. https:// doi.org/10.1007/s

Neaum, S. (2010). Child Development for Early Childhood Studies. Learning Matters Ltd.

Negen, J., \& Sarnecka, B. W. (2012). Number-concept acquisition and general vocabulary development. Child Development, 83(6), 2019-2027. https://doi.org/10.1111/j.14678624.2012.01815.x

O'Grady, W. (2005). How children learn language. In How Children Learn Language. Cambridge University Press. https:// doi.org/10.1017/CBO9780511791192

Oller, D. K., Buder, E. H., Ramsdell, H. L., Warlaumont, A. S., Chorna, L., \& Bakeman, R. (2013). Functional flexibility of infant vocalization and the emergence of language. Proceedings of the National Academy of Sciences of the United States of America, 110(16), 6318-6323. https:// doi.org/10.1073/pnas.1300337110

Olsson, L. M. (2013). Taking Children's Questions Seriously: The Need for Creative Thought. Global Studies of Childhood, 3(3), 230-253. https://doi.org/10.2304/gsch.2013.3.3.230

Owens, R. E. (2012). Language Development: An Introduction (8th ed.). Pearson Education, Inc.

Pandean, M. L. M. (2018). Kalimat tanya dalam bahasa Indonesia. Kajian Linguistik, 5(3), 7588.

Rakoczy, H., \& Tomasello, M. (2009). Done wrong or said wrong? Young children understand the normative directions of fit of different speech acts. Cognition, 113(2), 205-212. https:/ / doi.org/10.1016/j.cognition.2009.07.013

Raymond, G. (2010). Grammar and social relations: alternative forms of yes/no-type initiating actions in health visitor interactions. In A. F. Freed \& S. Ehrlich (Eds.), Why do you ask? The function of questions in institutional discourse (pp. 87-107). Oxford University Press.

Rohmah, Z., Yulianto, B., \& Mintowati, M. (2019). Pemerolehan kalimat tanya bahasa Indonesia anak prasekolah usia 5-6 Tahun. Belajar Bahasa, 4(2), 161-168. https:// doi.org/http://dx.doi.org/10.32528/bb.v4i2.2122 Diterima:

Rowland, C. F. (2007). Explaining errors in children's questions. Cognition, 104, 106-134. https:/ / doi.org/10.1016/j.cognition.2006.05.011

Santos, M. E., Lynce, S., Carvalho, S., Cacela, M., \& Mineiro, A. (2015). Mean length of utterance-words in children with typical language development. Revista CEFAC, 17(4), 1143-1151. https:// doi.org/10.1590/1982-021620151741315

Santrock, J. W. (2011). Child Development: An Introduction (13th ed.). McGraw-Hill.

Setyadi, A. (2018). Pemakaian Partikel kah dalam Kalimat Tanya. Nusa: Jurnal Ilmu Bahasa Dan Sastra, 13(2), 231. https:/ / doi.org/10.14710/nusa.13.2.231-243

Sidnell, J. (2010a). Questioning repeats in the talk of four-year-old children. In H. Gardner \& M. Forrester (Eds.), Analysing Interactions in Childhood: Insights from Conversation Analysis (pp. 103-127). Wiley-Blackwell.

Sidnell, J. (2010b). The design and positioning of questions in inquiry testimony. In A. F. Freed \& S. Ehrlich (Eds.), Why Do You Ask?: The Function of Questions in Institutional Discourse (pp. 20-41). Oxford University Press.

Solehuddin, M., Gunawan, W., \& Kurniawan, E. (2019). Kindergartners' morphological awareness, its instruction and guidance in the Indonesian context. Indonesian Journal of Applied Linguistics, 9, 138-147. https://doi.org/10.17509/ijal.v9il.16887

Sorsana, C., Guizard, N., \& Trognon, A. (2013). Preschool children's conversational skills for explaining game rules: communicative guidance strategies as a function of type of relationship and gender. European Journal of Psychology of Education, 28(4), 1453-1475. https:// doi.org/10.1007/s10212-013-0175-4

Steensig, J., \& Drew, P. (2008). Introduction: Questioning and affiliation/ disaffiliation in interaction. In Discourse Studies (Vol. 10, Issue 1, pp. 5-15). 
DOI: $10.31004 /$ obsesi.v5i2.785

https://doi.org/10.1177/1461445607085581

Stemberger, J. P. (2014). Perseveration and speech errors in child language production. In Encyclopedia of Language Development (pp. 440-441). SAGE Publications, Inc.

Sunggingwati, D., \& Nguyen, H. T. M. (2013). Teachers' questioning in reading lessons: A case study in Indonesia. Electronic Journal of Foreign Language Teaching, 10(1), 80-95.

Tracy, K., \& Robles, J. (2009). Questions, questioning, and institutional practices: An introduction. In Discourse Studies (Vol. 11, Issue 2, pp. 131-152). https:// doi.org/10.1177/1461445608100941

Valian, V., \& Casey, L. (2003). Young children's acquisition of wh-questions: The role of structured input. Journal of Child Language, 30(01), 117-143. https://doi.org/10.1017/S0305000902005457

Wagner, L., Greene-Havas, M., \& Gillespie, R. (2010). Development in children's comprehension of linguistic register. Child Development, 81(6), 1678-1686.

Weber, E. G. (1993). Varieties of Questions in English Conversation (Vol. 3). John Benjamins Publishing Company. https:// doi.org/10.1075/sidag.3

Yang, C. (2016). The Price of Linguistic Productivity: How Children Learn to Break the Rules of Language. The MIT Press.

Zaim, M. (1998). The Acquisition of Questions by Indonesian Adult Learners of English (Issue October). University of Tasmania at Launceston. 